\title{
MAKING WAVES: PRIVATE RADIO AND LOCAL IDENTITIES IN INDONESIA ${ }^{1}$
}

\section{Jennifer Lindsay}

Despite the Republic's policy of state monopoly of the airwaves during the Indonesian Orde Lama (Old Order) period (1945-1966), radio broadcasting in Indonesia has a strong tradition as local community activity. Today in Indonesia, private radio continues to flourish, with the number of stations increasing annually. In 1997, of a total of 898 radio stations in the country, seven hundred of them were private-all commercial, and all tailoring their programming to local community audiences that were more and more narrowly defined. ${ }^{2}$ Addressing regional identity on the airwaves, which is an expression of local community focus, takes on different meanings over time and in different localities. Programming on private radio-which must be popular with its listeners and attractive to advertisers-reveals the changing and ambiguous forms of regional identity at a local level.

\section{Beginnings}

When radio first came to the Netherlands East Indies in the early 1920s, it was at the outset a participatory listener-oriented activity with community interest equally

\footnotetext{
${ }^{1}$ Drafts of this paper were presented at the 20th anniversary ASAA meeting at La Trobe University, Australia, July 8-12, 1996 (titled "On Air: Private Radio and Regional Identity in Indonesia") and at Arizona State University's conference "Reflecting on the Old and New in Modern Indonesia," June 13-15, 1997 (titled "Local waves: Private Radio in Indonesia"). In revising the paper for publication in Indonesia, I benefited from the valuable comments and suggestions of an anonymous reviewer, for which, thanks.

${ }^{2}$ Media Scene 1996-1997 (Jakarta: Persatuan Perusahan Periklanan Indonesia, 1997), p. 29.
} 
strong in broadcasting and reception. ${ }^{3}$ Legal radio broadcasting commenced in 1925 when Bataaviasche Radio Vereening (BRV), run by a group of radio enthusiasts in Batavia, began airing programs of western music, broadcasting from a room in the Hotel des Indes. Begun as a listeners' initiative with its own listeners' society paying for program costs, BRV's finances later became supplemented by advertising. Only in 1934, when BRV became the official government broadcasting channel renamed NIROM (Nederlands Indische Radio Omroep Maatschappij), were the listeners' society's financial contributions replaced by officially determined license fees collected from all wireless receiver holders.

Between BRV's first broadcast in 1925 and its designation as the first official government station in 1934, radio developed quickly in the Indies. By 1942 and the effective end of the Dutch colonial era, it had developed characteristics that were unusual compared with those of neighboring colonies: radio was initially totally privately run; it became equally a private and government affair with no monopolization of the technology by colonial authorities; it was primarily a medium for entertainment and culture rather than news and information; and there existed two parallel and complementary broadcasting systems, one operated by and directed to Europeans, and one operated by and directed to "Easterners."

The new medium of radio represented a technological breakthrough in both communication (following from the telegraph) and in the mechanical transmission of recorded music (following the gramophone). Both earlier technologies had been introduced to the colony around the turn of the century. Shortwave broadcasting permitted direct communication between colonies and home countries, with instant transmission of news and aired voices from distant places. Whereas in many other countries and colonies the content of radio transmissions and even the vision of radio's potential remained circumscribed inside this information framework (government broadcasting monopolies developed national networks in Malaysia and India, for instance, where radio was modeled on or directly broadcast from the BBC), in the Netherlands East Indies the new international technology of broadcasting quickly came to be applied to a more cultural role and to localized, community-run expressions. ${ }^{4}$ Mangkunegara VII, the princely ruler in Surakarta, epitomized this process. In 1927, he sat in his palace, tuned in to his wireless set and listened

${ }^{3}$ On history of radio see Sedjarah Radio di Indonesia (Djakarta: Kempen, Radio Republik Indonesia, 1953); Colin Wild, "Indonesia: A Nation and its Broadcasters," Indonesia Circle 43 (1987): 15-40; M. Slamet, "Radio Siaran Swasta Ada Sejak PD 1," Eksponen Minggu II (September 1993): 5; A. Suroto, Dari Gelombang ke Suara (Djakarta: Balai Pustaka, 1953). Readers are referred to these articles, especially Wild, for a summary of the early history of radio broadcasting in Indonesia. A short summary is given in the introduction to Petunjuk Radio Siaran Swasta Nasional '95 (Jakarta: Pengurus Pusat, Persatuan Radio Swasta Nasional, 1995), pp. 19-21.

${ }^{4}$ For developments in India see David Lelyveld, "Upon the Subdominant: Administering Music on AllIndia Radio," in Consuming Modernity: Public Culture in a South Asian World, ed. Carol A. Breckenridge (Minneapolis/London: University of Minnesota Press, 1995) pp. 49-65; and P. C. Chatterji, Broadcasting in India, 2nd ed. (New Delhi: Sage Publications Inc., 1991). For the history of radio in Malaysia and a summary of broadcasting in Indonesia see Drew O. McDaniel, Broadcasting in the Malay World (New Jersey: Ablex, 1994). 
spellbound to the voice of Queen Wilhelmina broadcast live from the Netherlands. ${ }^{5}$ Only six years later he founded his own radio station-the first "Eastern" radio station in the Indies-choosing to broadcast live performances of Javanese gamelan music. ${ }^{6}$

Mangkunegara VII's example in using radio for cultural expression was not unusual. The new medium of radio in the Indies had Dutch broadcasting as its model, which emphasized radio's cultural rather than political role and did not pursue state monopoly of the airwaves. ${ }^{7}$ In 1934, when it was Queen Wilhelmina's turn to be astounded by direct royal communication from the Indies, that communication came in the form of gamelan music broadcast live from the Sultan's palace in Yogyakarta as the accompaniment to a dance that was being simultaneously performed in the Queen's presence in the Hague. ${ }^{8}$ The technological wizardry directly linking the Javanese palace and the Dutch queen had a purely cultural expression.

In the Netherlands East Indies over the late 1930s, radio became predominantly a medium for culture and entertainment, with music dominating the programming. Government regulation kept it that way-with restrictions against political or religious broadcast-a model that continues in private radio in contemporary Indonesia. ${ }^{9}$ By 1939, the official Netherlands East Indies station NIROM devoted a full 80 percent of broadcast time to music, of which Mrázek calculates three-fourths was played from gramophone records, and of all this music broadcast, 81 percent of it was in the "light classical" or "light music and cabaret" category. ${ }^{10}$ In some ways, the early Indies nonEastern radio stations functioned like gramophone clubs, with their listeners' societies sharing musical tastes and information on recordings. Certainly the development of radio in the Netherlands East Indies-particularly the non-Eastern radio stationsmust be seen progressing hand-in-hand with the gramophone and the $78 \mathrm{rpm}$ record, with each technology reinforcing the other. Although the gramophone had been introduced to the Netherlands East Indies at the turn of the century, prices for both gramophones and $78 \mathrm{rpm}$ records did not begin to decrease until the mid 1920s, precisely the time of the development of radio. ${ }^{11}$

${ }^{5}$ Wild, "Indonesia," pp. 18-19, quoting S. Mangoenkoesoemo, Het Triwindoe-gedenkboek Mangkoe Nagoro VII (Solo, 1939), p. 181.

${ }^{6}$ Rudolf Mrázek, " 'Let Us Become Radio Mechanics': Technology and National Identity in Late Colonial Netherlands East Indies," Comparative Studies in Society and History 39,1 (January, 1997): 3-33, especially p 9. Mangkunegara VII's station, the Solosche Radio Vereeniging (SRV) was founded in 1933 and began broadcasting in 1934.

7 See Wild, "Indonesia."

${ }^{8}$ Mrázek, "Let Us Become Radio Mechanics," p. 9.

${ }^{9}$ Mrázek, "Let Us Become Radio Mechanics," p. 10, quotes Marjan Beijering "Overheidscensuur op een koloniale radiozender: De Philips Omroep Holland Indie en de Indie Programma Commissie, 1933-1940," in Jaarboek Media Geschiedenis 4 (1992): 53-59.

10 Mrázek, "Let Us Become Radio Mechanics," p. 21, summarizes statistics from René Witte, "Exploitatie en bevoogding: De Europese en inheemse radio-omroep in Nederlands-Indië tot 1942," in Jarrboek Media Geschiendenis, 4 Nederlands-Indië (Amsterdam: Stichting beheer IISG, Stichting Mediagescheiedenis, 1992), p. 29.

11 Information kindly supplied by Philip Yampolsky (personal correspondence, June 1997). Gramophones, though, remained cheaper than radios. Yampolsky explains: "Throughout the 1930s, the standard price for a gramophone record was $\mathrm{f} 2-\mathrm{f} 2.50$. Outdated stock was sold for much cheaper ... In the mid-30s, low-end new gramophones cost in the range of $\mathrm{f} 18$ to f80. Used ones of course cost less. In 1938, the cheapest radio 
108 Jennnifer Lindsay

The "Eastern" (Ketimoeran) private stations that blossomed over the 1930s, however, specialized in broadcasts of local music, aired live. ${ }^{12}$ This was so despite the fact that by the mid-1930s there was a remarkable wealth of local music commercially available on $78 \mathrm{rpm}$ recordings. Philip Yampolsky calculates that around ten thousand discs of local Indies music were recorded for the combined Netherlands East Indies/Malayan markets between 1903-1942, with the heyday of this recording in the 1930 s and coinciding with the introduction of radio. ${ }^{13}$ Yet although there was an active local recording industry, the available selection of local music was still limited compared with the much wider selection of $78 \mathrm{rpm}$ recordings of imported western music that were the basic fare for the BRV/NIROM radio system. In the peak years of gramophone record import, namely the late 1920s before the Depression, over one and a half million records were being imported per year. In the 1930s, this figure declined, but imports still averaged between three hundred thousand to five hundred thousand per year. ${ }^{14}$

The Ketimoeran stations' decision to broadcast live performances, though, appears not to have been merely a factor of the availability or not of recordings. Broadcast of live local music seems to have been their chief vision of radio. On the one hand, the urge to broadcast their own music may have been part of a "civilizing mission." Mangkunegara's broadcasts of his palace musicians, for example, brought "palace art" to any listeners with access to a receiver, at a time where other princely housesparticularly in Yogyakarta-were also "democratizing" their arts by making them available outside the palace. ${ }^{15}$ Live broadcasting added another dimension, though, by at once localizing something modern and modernizing something local. Mangunegara VII's broadcast of live gamelan music was a totally modern act. The transmission of local performance as disembodied sound was a phenomenon made possible through the technology of radio. Unlike gramophone recordings, radio permitted transmission of real performance in real time, for the music broadcast was neither limited to a three minute $78 \mathrm{rpm}$ format, nor was it a re-play. Radio offered a sense of marvel of immediacy (perhaps like e-mail today) of communication between performer and

I can find in my listings went for $\mathbf{f 7 4 . 5 0}$. Most cost around $\mathrm{f} 250$. So the cheapest radio was at the top of the low-end bracket for gramophones."

12 Other Indonesian broadcasting societies formed rapidly after Mangkunegara's start. By April 1934, SRV had opened a branch in Batavia which eventually became VORO (Vereeniging Voor Oosterse Radio Omroep), and the same month the Bandung station VORL (Vereeniging Oosterse Radio Luisterars) began broadcast Other stations founded in 1934 included a second station in Solo, Siaran Radio Indonesia (the first station to use the name "Indonesia"), Yogyakarta's MAVRO (Mataramsche Vereeniging Voor Radio Omroep), the Surabaya Chinese radio station VORS that was later called CIRVO (Chinescheen Inheemsche Radio Luisteraars Vereeniging OostJava) and the Madiun EMRO (Eerste Madiunsche Radio Omroep). In 1936 Semarang opened a branch of SRV, Radio Semarang.

13 Philip Yampolsky, "The Transition from Traditional to Popular Music in Indonesia: Three Contrasting Trajectories," paper presented at the Sean O'Riada Conference on Traditional Music, Popular Music, and Identity, University College Cork, Cork, Ireland, March 2-3, 1996.

14 Yampolsky (personal correspomdence, June 1997) summarizes figures from 1912-1940.

15 For example, one may note Pangeran Suryodiningrat's establishment of Krida Beksa Wirama and later the Pakempalan Kawulo Ngayogyakarta, and Ki Hadjar Dewantara 's teaching of Javanese dance and gamelan at Taman Siswa in the 1930s. See further Jennifer Lindsay, "Klasik, Kitsch or Contemporary: A study of the Javanese Performing Arts." Unpublished PhD dissertation, University of Sydney, 1985. pp. $15-22$. 
receiver disconnected physically. The wonder of the new technology of radio was made even more impressive, then, by the familiarity of the content. The live electronic transmission of music of the listener's own locality, familiar as live, embodied performance-this was something new.

By the end of the colonial period, radio broadcasting in the Indies had settled into a dualistic system, divided both in terms of private and state, and in terms of east and west. By 1942, at the time of the Japanese occupation, the official state channel NIROM had studios in Jakarta, Bandung, Surabaya, Semarang and Medan, with relay stations in Solo, Yogyakarta, Cepu, Malang, Sukabumi, Cirebon, Bogor and Padang. Official news broadcasts were made though this channel. There were four private Dutch radio stations, one each in Jakarta, Bandung and two in Yogya. ${ }^{16}$ The Ketimoeran private stations had already reached eight in number by 1937, located in Batavia, Bandung, Surabaya, Yogyakarta, Madiun, Semarang, and two in Solo. In 1937, those eight stations were grouped together as a broadcasting association, the Federation of Eastern Radio Societies (Perikatan Perhimpoenan Radio Ketimoeran, PPRK), which articulated its mission as "the furtherance of native culture . . ."17 The separation of missions of the two systems was staunchly maintained by the Ketimoeran group. When in 1936 NIROM announced that it would henceforth produce its own local music programming, the Ketimoeran radio stations protested. In 1937, the newly formed PPRK, led by Volksraad member Soetardjo Kartohadikoesoemo, successfully lobbied the NEI government for this association to control broadcast of Ketimoeran material and to maintain airtime on NIROM stations for local Ketimoeran broadcast. 18

Compared to statistics from neighboring colonies, figures measuring the radio audience in the Indies were high, with the non-European listening audience in general on parity with European. By 1939, forty-two thousand radio receiving licenses were held by "natives and other Asiatics" compared with forty-five thousand for Europeans. ${ }^{19}$ And although the two systems-east and west-targeted eastern or western audiences, in fact there was considerable cross-over of listening, particularly in the case of "native" listening to the non-eastern channels. Mrázek's research of radio in this period in the Netherlands East Indies, referring to figures gathered by Soetardjo, the head of the Federation of Eastern Radio Societies, reveals that by 1938 this federation involved about six thousand listeners, of whom two hundred were European. In the same year the non-Eastern Indies radio subscribers numbered 31,857 Europeans and 21,706 "natives" and "other orientals." The Federation of Eastern Radio

\footnotetext{
16 The van Wingen company also had small stations for advertising its goods in Jakarta, Surabaya, Semarang, Solo, Malang and Bandung. See Sedjarah, p. 224.

17 This articulation of the mission of radio as an ally of native culture contrasted sharply with a Dutch musicological purist idea of the "fatal work of radio" wreaking destructive havoc on indigenous musical traditions "greater than a sledge hammer or a stick of dynamite." Johan Huizinga, De Gids 91,1 (January 1928), quoted in Frances Gouda, Dutch Culture Overseas (Amsterdam: Amsterdam University Press, 1995), p. 222.

18 As Yampolsky (1996) points out, the fight over broadcasting of "eastern material" was basically a fight over the contested area of popular music genres of keroncong and stambul.

${ }^{19}$ Wild, "Indonesia," p. 19, quoting R. D. Haslach, Netherlands World Broadcasting (Media, Pennsylvania: Laurence Miller Publishing, 1983), p. 34.
} 
110 Jennnifer Lindsay

Societies, then, covered about 25 percent of the total Eastern listeners in the Netherlands East Indies. ${ }^{20}$

In 1942, the Japanese occupied the Netherlands East Indies and the world of radio changed dramatically. If radio had to date been apolitical (Mrázek, interpreting radio's development in the Netherlands East Indies as a betrayal of Kartini's vision of modernity, would say "a frivolity"), things suddenly got serious. As Wild has pointed out, comparing the broadcasting systems under the Netherlands East Indies and Japanese governments and the models these provided for the emergence of Indonesian radio, the Japanese model of broadcasting now introduced was "rigidly censored, government controlled, and totally devoted to the purpose of furthering national policy and conditioning the public mind to accept and applaud national aims." 21 Installing a new model of centralized government-controlled monopoly of the airwaves, the Japanese set up a central station in Batavia with fifteen branch stations: seven in Java, five in Sumatra, and one each in Makassar, Manado, and Banjarmasin, all with Indonesian staff. Although broadcasts consisted primarily of war propaganda, programming was permitted in Indonesian, and broadcasts of Indonesian music encouraged.22 Community-oriented private radio went off the air until 1966.

\section{Indonesia}

On September 11, 1945, less than a month after the declaration of independence (which had also been broadcast on radio), Indonesian broadcasters met in Batavia to demand control of the Japanese-installed centralized broadcasting system, which was taken over by the Republican movement and renamed Radio Republic Indonesia(RRI). ${ }^{23}$ While the republican movement was setting up the RRI system, (the central studio moved to Solo in 1946), the Dutch established the rival ROIO (Radio Omroep in Overgangstijd) in 1948 which, after international acceptance of Indonesia's independence in December 1949, joined with RRI to become the new Radio Republik Indonesia Serikat. On August 17, 1950, the name reverted to Radio Republik Indonesia (RRI). Independent Indonesian stations that had appeared during the 1945-1949 period that had broadcast support for the revolution disappeared, their role now filled by RRI. 24

The private radio societies of the late colonial period did not reappear in the new republic. Many radio enthusiasts turned to "amateur" HAM radio, communicating

\footnotetext{
${ }^{20}$ Mrázek , "Let Us Become Radio Mechanics," p. 25, quoting Soetardjo's Volksraad speech of August 8, 1938, Handelingen van den Volksraad (1938-39), p. 778. PPRK's total membership figure of six thousand included thirteen hundred Chinese, two hundred European and 160 Arabs. Indies subscribers in 1938 included 31,857 European, 12,238 "native" and 9,468 "foreign Oriental." Compared to the figures for India seven years later, these figures for Indonesia in 1939 are remarkably high. Lelyveld points out that on the "eve of Indian independence," the total number of license-holders in India was about ninety thousand. Lelyveld, "Upon the Subdominant," p. 54.

21 Wild, "Indonesia," p. 23.

22 Wild, “Indonesia," p. 29.

${ }^{23}$ The declaration of independence was read on Jakarta Hoso Kyoku by Jusuf Ronodipuro on the evening of August 17, 1945. Wild, "Indonesia," p. 30.

${ }^{24}$ Radio Indonesia Raya and Radio Militer in Yogyakarta; Radio Perjuangan in Semarang; Radio Pemberontakan in Solo; Radio Gelora Pemuda in Madiun and Radio Pemberontakan in Surabaya.
} 
internationally and forming their own Indonesian association PARI (Persatuan Amatir Radio Indonesia) in $1947 . .^{25}$ RRI was given sole authority for broadcasting, and in 1946 became a department of the Ministry of Information. In the same year broadcasting legislation was introduced, which stipulated that there be only one centralized RRI news broadcast, required all radio receivers to be registered and set radio license fees. ${ }^{26}$ New stations opened in Madiun, Jember, Pontianak and Ambon, so that by 1953 there was a total of twenty RRI stations. ${ }^{27}$ But although RRI was now the official information channel for the government and maintained monopoly of national news broadcast, it did not become merely a mouthpiece of centralized government information. RRI actually also took over many of the programming functions of the pre-Japanese Ketimoeran stations and allotted a large percentage of broadcasting time to localized content. The language of broadcast was Indonesian, although local branch RRI stations were given considerable flexibility to air cultural programs in regional languages.

Over the Old Order period (1945-1966), restrictions were made on the types of music broadcast, with certain kinds of popular music (Soekarno's term of disparagement for groups like the Beatles or Indonesia's Koes Plus was "musik ngak ngik $\left.n g o k^{\prime \prime}\right)$ forbidden. The type or style of cultural content broadcast on the radio now had to be officially sanctioned. Alongside with the development of RRI as national radio during the Orde Lama period, was the establishment of a state recording company, Lokananta, which, like RRI, became a branch of the Department of Information. ${ }^{28}$ As Yampolsky points out, Lokananta's predecessor, Indravox, was in fact established with the sole aim of providing music for RRI broadcast. The type of local music that was selected by Lokananta to record was also specifically chosen to represent group performance, complexity and heritage, basically music considered to be "respectable." 29 Live music broadcasts on radio were made with the same consideration, and even today RRI officially omits certain kinds of music (dangdut for instance) from its programming.

\section{The New Order and the Reemergence of Private Radio}

Private radio reemerged in Indonesia in the transitional period between the Old and New Orders, as part of the student movement of 1966. Named "radio amatir," (in

25 Suroto, Dari Gelombang ke Suara, pp. 62, 83-86. The existence of HAM radio as an amateur activity in the Netherlands East Indies period, and also in the early Republic, could have answered the need for radio enthusiasts who wished to use the medium for (more serious ?) informational and international communications, leaving broadcasting for more leisurely cultural pursuits (or frivolity). The HAM radio enthusiasts during the NEI period also formed an association, the Nederlandsch Indische Radio Amateurs Vereeniging (NIRAV), based in Surabaya.

26 Suroto, Dari Gelombang ke Suara, pp. 90-92 and the 1947 amendments pp. 93-95. By 1953, the license fees were $\mathrm{Rp} 5$ per radio receiver.

27 These were the four cities where radio stations had not previously existed under the Japanese system. The other RRI stations were in Jakarta, Bandung, Cirebon, Semarang, Solo, Yogyakarta, Surabaya, Denpasar, Palembang, Padang, Bukittinggi, Kutaraja, Medan, Makassar, Banjarmasin, and Menado.

28 For a definitive history of Lokananta, see Philip Yampolsky, Lokananta A discography of the national recording company of Indonesia 1957-1985 (Madison, Wisconsin: Center for Southeast Asian Studies, University of Wisconsin, 1987). In 1961, Lokananta was detached from RRI and made a state company.

29 Yampolsky, Lokananta, p. 23. 
contrast to the non-broadcast HAM "amatir radio") student-run transmitters ran an alternative information service that challenged the official news on RRI and also broadcast western popular music that had been discouraged nationally and banned from RRI broadcasts during the Old Order. These "radio amatir" emerged soon after the abortive September 1965 coup. The following February, two student radio stations started broadcasting within a week of each other-Radio Ampera in Bandung, which had military support, and the Radio Kami (Kesatuan Aksi Mahasiswa Indonesia) in Jakarta. Other groups immediately followed this lead. By 1967 there were already twenty student transmitters in Jakarta and fifty in Bandung. ${ }^{30}$

Private radio transmission boomed over the late 1960s, and in a time of no regulation, literally hundreds of stations emerged and competed fiercely for airwave frequencies. The blossoming of private radio and the subsequent battle for airwave frequencies led to government intervention in 1970. The government did not outlaw private radio, but instituted legislation that defined its roles and duties (to uphold the principles of the state ideology Pancasila and the 1945 Constitution) and its overall broadcast format (educational, entertainment and information-news broadcasts not permitted), and that required all radio stations to register as commercial businesses. ${ }^{31}$ The official designation for private radio then became "radio swasta," replacing the term "radio amatir," which apart from its connotations of non-professionalism, was also easily confused with HAM "amatir radio." Over the next few years, increasingly complex regulations were implemented for annual frequency permits, and the total number of private broadcasters decreased. By 1974, when the National Broadcaster's Association (PRSSNI) was established, there were 217 officially registered private radio stations in Indonesia. ${ }^{32}$

Although private radio reemerged in Indonesia in 1966 as an information source in opposition to state-owned RRI, once the New Order was installed it rapidly regained its former role as a source of community information and entertainment. RRI became the official media voice of the new government. Government broadcasting legislation in 1970 gave sole control of news broadcasting to RRI and clearly relegated private radio's role to "education, and a tool of information and entertainment to bring about the success of the government's program." 33 Private radio continued to develop within a commercial setting, supported by advertising, which was excluded from RRI. Following the flurry of activity in the late 1960s and the stabilizing 1970 legislation, the number of registered stations has since steadily increased despite the introduction of

30 See further Wild, "Indonesia," pp. 35-36, for a summary of the activities of these student-run transmitters.

31 The Peraturan Pemerintah (PP) 55. For the text of this legislation for private radio and later amendments see Petunjuk Radio Siaran Swasta Nasional '95 (Jakarta: Pengurus Pusat, Persatuan Radio Swasta Nasional, 1995), pp. 453-458.

32 PRSSNI figure-provided by Errol Jonathans. I have been unable to obtain a figure indicating the number of stations established before the impact of the 1970 legislation, but according to Errol Jonathans, the number of transmitters was enormous, and in East Java alone there were more than six hundred transmitters competing for airwave frequencies.

33 See paragraph 2 of the 1970 legislation which stipulates "Sudah menjadi kewajiban bahwa penyelenggaraan Radio Siaran tersebut harus berfungsi sosial, yaitu sebagai alat pendidik, alat penerangan dan alat hiburan dan dengan demikian akan ikut mensukseskan program Pemerintah," Petunjuk Radio Siaran Swasta Nasional'95, p. 455. 
national television in the 1970 s and commercial television in the $1990 \mathrm{~s} .{ }^{34}$ In 1997 , the total number of registered private radio stations in Indonesia stands at around seven hundred. ${ }^{35}$

The government-owned radio system in Indonesia, other than the fifty-three RRI stations, also includes the 146 regional-government (Pemda tingkat II) run "special" stations, called Radio Khusus Pemerintah Daerah or Radio Siaran Pemerintah Daerah, which are supposed to broadcast using RRI frequencies and relay much RRI material. As with RRI, the PKPD and PSPD are free of the tax and permit requirements imposed on private radio, and as non-commercial entities are not supposed to accept sponsorship or broadcast advertising. Recently, however, many regional government stations have flaunted these regulations, moving to FM, accepting advertising, and even "sub-leasing" the entire operation of the station to private managers. This increasingly blatant encroachment on the world of private radio is under strong attack from the private broadcasting sector, which defends its commercial identity (albeit with all the resulting tax and permit implications) against government non-commercial broadcasting. ${ }^{36}$

The number of private radio stations in Indonesia is controlled through the requirement for all private radio stations to obtain annual frequency permits. ${ }^{37}$ This expensive, intricate, and time-consuming annual permit process functions as a government control mechanism to supervise programming and management, similar to the print media licensing controls. Prior to 1973, broadcasting permits were issued by regional governments, but following the 1970 legislation requiring the registration of private radio stations as businesses, the permit procedure became more complex, involving four different ministries: the Department of Information, the Department of Industry and Trade, the Department of Justice and the Department of Tourism, Post and Telecommunications.

Institutionalization of permit procedure in 1973 went hand-in-hand with the establishment of the National Broadcasters' Association, PRSSNI (Persatuan Radio Siaran Swasta Nasional Indonesia) which was established in 1974, and in 1977 was officially declared by the government to be the sole national broadcasters' association, amalgamating previous associations like Persatuan Radio Siaran (PRS) and local

\footnotetext{
34 In 1974, there were 217 stations (PRSSNI figure). Between 1975-1980 the national television TVRI was introduced, carrying advertising, but in 1981 advertising was banned on TVRI, giving a boost to private radio. In 1986 there were 360 private radio stations (Wild, "Indonesia," p. 37, quoting World Radio Handbook), and the number swelled in the late 1980s when FM radio was introduced. By 1989 there were 452 stations (PRSSNI figure), a year later (when private television started) there were 512, and by 1995 (when the first private television station, RCTI, went national), there were 439 AM and 223 FM stations. See Media Scene 1994-1995 (Jakarta: Persatuan Perusahan Periklanan Indonesia, 1996).

35 Figures vary. In September 1997, PRSSNI claimed 711 registered private radio stations. See Kompas (September 15, 1997): 4. The same month, the director of RRI stated there are "around 800 " private stations, a figure which might be an inflated guess or might include stations without permits and not registered with PRSSNI. See Kompas, September 14,1997, p. 13.

36 See, for example, Eksponen III (August 1997).

37 There are many small illegal "wild" broadcasters, not registered with PRSSNI, especially in areas further from the center. According to Kompas articles of December 12, 1995, p. 9; April 13, 1996, p. 15; and May 6, 1996, p. 10. Aceh has a total of eighty-three stations broadcasting privately, of which only thirtyone have permits, and twenty-six are PRSSNI members.
} 
114 Jennnifer Lindsay

broadcasters' associations which had formed to regularize frequency competition (Persatuan Radio Siaran Jakarta, Persatuan Amatir Radio Bandung and Persatuan Radio Siaran Jawa Tengah). ${ }^{38}$ PRSSNI has intimate government connections: the current head of PRSSNI, elected in 1989 and reelected in 1992 and 1995 for consecutive three year terms, is Mrs. Hj. Siti Hardiyanti Rukmana, with the Minister of Information appointed ex officio as "pelindung" (protector).

There is strong opposition from the private radio stations to the complicated licensing process currently in force, and although debate about this issue raged again in early 1997 with the revision of the broadcasting legislation, the requirements remain. The annual frequency permit requirement stands as a major obstacle to private radio stations seeking to maintain some independent control over programming and management. It also threatens their commercial existence, as the insecurity of a station's permit status from one year to the next makes it difficult for small stations to secure bank credit. Decisions on the permits are in fact made through a filtering system at a local level, with a regionally appointed body, the Badan Pembina Radio Siaran Non Pemerintah (BPRSNP), given the authority to make letters of recommendation for license renewal. This body is made up of members of provincial government, police and military, the local head of RRI, and provincial representatives of the Department of Justice and the Department of Information. There is no representation from private radio on the Board. ${ }^{39}$ The BPRSNP, apart from issuing the annual letters of recommendation for the renewal of the frequency permit, also approves the establishment of new stations, changes of location, selling of shares, changes in management, changes from AM to FM band, and regulations for transmitter power. ${ }^{40}$

Private radio stations in Indonesia are small businesses. There are no communitysupported non-commercial "public radio" stations, which would be a model closer to the early listener-club supported radio stations of the Netherlands East Indies in the 1930s. Private radio stations today have shareholders and are bought and sold as profit-earning enterprises. A mid-ranking station can be bought for around \$US90,000.41 Stations are owned by shareholders, and often one of the shareholders works as station director. The number of shareholders can be large for a relatively small station: Radio Mara in Bandung, for example, is owned by a group of twentyseven people. ${ }^{42}$ Usually staffed by around twenty to twenty-five people, a small station can earn profit income of between seven to ten million rupiah a month ( $\$$ US3000-4500), a larger station around four times that amount, and a successful top-twenty Jakarta station can earn around up to $\$ \mathrm{US} 100,000$ per month profit.

${ }^{38}$ A history of PRSSNI and chart of 1995-98 cabinet is given in Petunjuk Radio Siaran Swasta Nasional '95, pp. 19-21 and 12. See also Eksponen II (March 1996): 9, for a chart of the cabinet in 1996.

${ }^{39}$ The BPRSNP was established officially in April 1971. For the text of the Surat Keputusan see Petunjuk Radio Siaran Swasta Nasional '95, pp. 456-458. For further on the BPRSNP see Eksponen IV (April 1994): 3.

40 Regulations stipulate 250 watt transmitters for $\mathrm{AM}$ radio and 100 watt for FM giving a maximum broadcast distance of between three hundred to four hundred kilometers for AM stations, and up to one hundred kilometers for FM. In practice, most FM stations broadcast with at least 5 kilowatt transmitters, and some as much as 20 kilowatt, following the uncensored trend set by Jakarta top-twenty FM stations like Triyjaya, Prambors and Mustang.

${ }^{41}$ See, for example, figures describing the investment made by purchasers of Radio Muara 904 FM, Republika (April 13, 1996). 
Income is earned from advertising, but total time allotted to advertising may not exceed 25 percent of a station's broadcast time. With the introduction of commercial television, the proportion of advertising falling to radio has dropped severely and continues to fall, with private television claiming an ever higher percentage of the total advertising pie. In 1989, in the first three months of Indonesia's first private television station, RCTI managed to attract 6 percent of total advertising for that year. By 1992, official figures showed that 36.7 percent of total advertising went to newspapers, 9.3 percent to magazines, 9.7 percent to radio, 39 percent to television, 1 percent to cinema, and other media received 5.4 percent. By 1995, private television had secured 50 percent of total advertising, and the figure is still rising. ${ }^{43}$ Given this picture, it seems even more remarkable that private radio survives. However while television takes an ever-increasing percentage of total advertising, it also creates an overall larger advertising budget, with total advertising funds increasing about 40 percent annually, so that in fact while the percentage falling to radio decreases-by 1996 to only around 7 percent of the total advertising budget-radio advertising in actual money terms has increased (from US $\$ 43,000,000$ in 1992 to $\$ 64,500,000$ in 1995). 44

\section{Local Role of Private Radio}

The local role of private radio in Indonesia today is determined by three things: the enduring tradition of community and local focus; increased competition for advertising which encourages more specific targeting of audiences; and legislation.

Private radio in Indonesia may not broadcast nationally. Broadcasting legislation explicitly states the local role of private radio, legislating that role in terms of transmission power (which consequently limits broadcast area) and by defining the "nature" of private radio as properly focused on local programming. ${ }^{45}$ Further restrictions apply to the creation of any information programming of a national nature-particularly the news, which must be broadcast by relay from RRI. The dualism of the radio system in contemporary Indonesia, then, (despite the irregularities of the regional government stations) is drawn along private/local versus government/ national lines.

The persistent survival of private radio, though, within such a restrictive system, indicates the vitality of the Indonesian tradition of local community expression through radio broadcasting, a tradition that already existed in the late colonial period and resurfaced in private radio in 1966. Within the regulatory framework, private

42 See "Rumor, Mengudarakan Suara Masyarakat," Kompas, February 3, 1995, p. 17.

43 See Gutomo Bayu Aji and Eryanto, "Iklan Radio Di Tengah Persaingan Antar Media," Eksponen III (September 1994): 12 and interview with Drs. Ishadi, S. K. "Radio Terbelenggu Peraturan," Eksponen II (January 1995): 3. See also Media Scene 1994/95, p. 49.

44 Eksponen IV (January 1995): 1, 3, 4; and Eksponen II (January 1995): 4. The figures are: 1992, Rp 100 billion; 1993, Rp 113 billion; 1994, Rp 122 billion; and 1996, Rp 150 billion. The total advertising budget for 1995 is quoted as $\mathrm{Rp} 2.5$ trillion, or US $\$ 1,075,000,000$.

45 Chapter 2 article 3 states " 'Siaran Setempat Lokal' ialah siaran yang dimaksud bagi penerimaan setempat sesuai dengan jarak jangkau yang ditetapkan (local service area)." Chapter 4 article 1 states "Siaran bersifat lokal, bukan nasional" and article 2 "Sifat, isi dan tujuan siaran mencerminkan hubungan erat dengan keadaan serta pertumbuhan daerah jangkauan siaran." See Petunjuk Radio Siaran Swasta Nasional' 95 , pp. 456-457. 


\section{Jennnifer Lindsay}

radio stations refine their own interpretations of what is "local." In the first place, this is done through a style of broadcast that stresses familiarity between the presenter and listener, and a prominent feature of private radio broadcast in general is the high level of community involvement in the broadcasting process, through programming that involves listeners phoning in to the station, on-air talk-back shows, request programs and community announcements. There are phone-in programs for recipes (Radio Pesona Gita, Jakarta), for barter (e.g. Radio FeMale, Jakarta), for comment on current events (Radio Mara, Bandung, Radio Trijaya, Jakarta), and for sex consultation and match-making (Radio Pesona, Male FM). Some stations also have associated performance clubs that fill a regular program slot, arranging the program themselves; for example there are the dangdut and keroncong clubs of Radio Mataram Buana Suara in Yogyakarta or the macapat club at Radio Suara MTB in Surabaya.

Addressing regional identity is another feature of the familiarity of local private radio, whether this be through addressing the shared sense of locality of the station and the listeners (Javanese in central Java) or by addressing a local community distinguished by its identification with another locality (the Javanese in Medan). Specific address to regional identity are achieved in various ways. A station might mix local language or accent into the Indonesian language used for broadcast; it might use familiar local terms; or it might deliberately and consistently use local terms of address for its listeners. Addressing regional identity may also be made through a more specific and thorough use of regional language, a strategy that is tolerated but not encouraged by the state regulations that require the language of a radio broadcast to be "good" Indonesian, although a proportion of regional language programming is permitted on private radio if it accompanies cultural programs. ${ }^{46}$

The wide availability of cheap local recorded material has benefited those stations interested in highlighting regional identity by their programming of regional music and cultural forms. The late 1960 s and the return of private radio coincided with the beginning of the cassette industry in Indonesia, involving both trade in foreign music cassettes (most often of pirated copies) and the recording of Indonesian music cassette. Over the period of private radio's re-emergence, the local recording industry boomed. ${ }^{47}$ The cassette format also permitted recordings of new types of local performance that had previously been difficult to record on disc because of the disc's time limitations. Wayang kulit, for example, could now be recorded on cassette, and has ever since become staple broadcast material for private radio stations targeting Javanese listeners. Just as the Indies radio stations were linked to developments in the gramophone and $78 \mathrm{rpm}$ records, private radio stations could now broadcast hours of

${ }^{46}$ Chapter 8 articles 1 and 2 of the legislation states "Bahasa pengantar siaran adalah bahasa Indonesia yang baik; Untuk mata acara kesenian daerah dapat digunakan bahasa daerah yang baik sebagai pengantar." See Petunjuk Radio Siaran Swasta Nasional '95, p. 457. The need of private radio to communicate in familiar language conflicts with the official policy for "baik dan benar" Indonesian on radio, and periodically there are moves to "clean up" the language. See "Dalam Menggunakan Bahasa Indonesia Lisan: Penyiar Radio Swasta Pioner," Eksponen IV (March 1995): 5 and Errol Jonathans "Selipan Bahasa Lokal, Warisan Budaya" Eksponen II (April 1995): 11. RRI has always broadcast in regional languages, free from restrictions requiring that those languages be used in cultural programs exclusively, for RRI is charged with the specific purpose of broadcasting government information and the news, and these broadcasts are targeted to reach those citizens who are not fluent in Indonesian.

47 Yampolsky, Lokananta, pp. 2, 6, 19-20. 
local music and performance (and imported music) for little investment. Costs of broadcasting wayang kulit or gamelan, for example, were now minimal. Live broadcasting of local music, which had been the hallmark of the Ketimoeran private stations in the 1930s, became more typically the fare offered by RRI (which had funds to support musicians). Private radio stations broadcasting local music turned more to cassettes, and the development of the local cassette industry now allowed private radio stations to air hours of Indonesian popular music as well as new kinds of regional cultural forms.

The other factor that shapes private radios' local identity is advertising. As commercial enterprises, private radio stations all over Indonesia must live from advertising income which is in turn determined by the popularity of their station and programming. With the introduction of commercial television, radios must compete even more for a reduced percentage of the advertising budget. A direct result of increased competition for radio advertising is the increased segmentation of audience, for a clear definition of audience allows a station to market its advertising slots more easily. The trend toward attracting and identifying increasingly segmented target audiences for private radio has become most marked in the 1990s. Whereas radio stations previously broadcast a variety of programming to a wide audience, now they determine their audiences more specifically in terms of economic status, age, gender, and in some cases, religion. An important factor in determining audience segmentation and programming, though rarely overtly acknowledged in station profiles, is affiliation to regional cultural identity.

When a radio station chooses how it will appeal to a sense or style of regional identity and decides which audience it will target with that appeal, this is a marketing decision. In general, varying degrees of use of regional language and cultural programming may be part of the overall image of the station. In more heterogeneous cultural situations (Medan, Jakarta, for instance) or where stations broadcast to transmigrant communities, then targeting ethnicity is in itself a clear way of marking one audience segment for marketing advertising. However, in more homogeneous cultural situations like rural and central Java, the ethnic identification of listeners is a given. Stations then must segment their audience in other ways, through addressing one kind of Javaneseness, for example, which may be achieved through a choice of the types of Javanese cultural forms or language broadcast or through the proportion of Javanese-oriented programs to other programming. Such stations then target their audience segments more through reference to age group, gender, and economic class.

Private radio stations must constantly update information on their audiences (information regarding economic class, cultural background, age group and gender) since their success will be determined by listener interest. To succeed at this, they require excellent feedback from their listeners in response to programming. The programming of private radio stations, then, provides a clear picture of how the stations see their audiences, and how they understand that their audiences, in turn, perceive the station. Thus, the match between the material stations select to broadcast and the station's determination of its audience in terms of age, gender, and income, reveals a great deal about the meaning and value given to regional cultural identity.

A survey of a number of private radio stations active in broadcasting regional cultural and/or language reveals a varied picture, illustrating the ambiguous position 
118 Jennnifer Lindsay

of regional identity in Indonesia. Sometimes, an overt expression of regional identity is synonymous with lower economic class, and radio stations selling that image of themselves for advertising are indeed often those that appeal to a lower-income audience segment. The more "Indonesian" and "modern" the radio station, the more expensive its advertising time and the more "high-class" the actual advertising. However, there are exceptions to this pattern. One such exception can by studied by tracing the prevalence of dangdut music, which is without doubt the most popular musical form broadcast all over Indonesia. Urban and not regionally-specific, dangdut is indeed Indonesian, yet is predominantly broadcast on low-income audience segment AM stations. Many private radio stations (and RRI stations) have initiated their own blanket policy restrictions against broadcasting dangdut because of its "cheap" image (perhaps analogous to certain radio stations in western countries that will play no country music). And yet this generalization too has striking exceptions, for two of Jakarta's top-listening radio stations, stations which attract a high percentage of midto upper income listeners, feature dangdut music, and a revamped FM station (Radio Muara 904FM) specializing in dangdut (which lists Rhoma Irama among its owners) is rapidly gaining in popularity with a "higher class" image. ${ }^{48}$

Some specifically regional cultural forms also seem to transcend all economic class divisions and are broadcast on various kinds of private radio stations. One outstanding example of such an art form is wayang kulit, broadcast widely in central Java (and to migrant Javanese communities in other regions). In Yogyakarta, even the most popular top-twenty radio station that targets a young student audience, Radio Geronimo, has a regular wayang kulit broadcast. Virtually all stations broadcast wayang kulit, usually from cassette recordings, but some also sponsor live performances. Stations address their specific audiences by differentiating broadcast times (Saturday night, Thursday night versus other week nights), performance genres (Yogya or Solo) and styles (established or new young dalangs, levels of innovation, levels of ribald humor).

Usually a change from AM to FM band signals that a particular station is seeking to target a more elevated, "high class" audience, a move that usually corresponds with an increase in the price of its advertising; such a shift typically entails "upgrading" programming to reflect a more urban format. ${ }^{49}$ Sometimes this transformation involves reducing the level of regional cultural content, adopting a more Jakartan image,

48 See M. Jamiluddin Ritonga and Asrul M Mustaqim's article "Evaluasi Riset Khalayak Radio," Kompas, September 10,1994, which looks at the situation in Jakarta and environs (Jabotek) and states that, contrary to the general opinion that radio in general is for the lower income group, in fact Jabotek radio listening is highest in the mid- to upper income range. Of forty-six radio stations in this area in 1994, only four stations had a listening audience of at least 5 percent of the population, and the top rating stations were Radio Kayumanis and CBB, which are both dangdut stations. CBB's listening audience is predominantly mid-income bracket, and Kayumanis has more listeners in the combined mid and upper income range than lower income. See also "Radio Muara 904 FM, Sebuah Gengsi Bernama Dangdut," Republika, April 13, 1996. The Jakarta Post, June 30, 1996, listed Radio Kayu Manis as the top ranking Jakarta radio station.

For an interesting discussion on the changing social role and status of dangdut music, see Gabriel Lono Simatupang Rooseno, "The Development of Dangdut and its Meanings: A Study of Popular Music in Indonesia." Unpublished MA thesis, Monash University, Australia, 1996.

49 This adoption of an urban Jakarta format occurs even though change to FM usually means a smaller broadcast area because of restrictions on transmission power. The important factor in the "upgrading" of a station's image and advertising when it switches to FM is the better sound quality, which stations claim appeals to a younger, wealthier audience. 
reducing the prevalence of localized, colloquial Indonesian, and adopting a general style that is recognized as more cosmopolitan and "modern." Sometimes it means altering the kind or the relative proportions of regional culture material broadcast, for example by decreasing ketoprak or ludruk while increasing broadcasts of wayang kulit or gamelan. In one unusual example to be discussed below, the change to FM actually involved an increase in regional language broadcast (Sundanese).

\section{The Image of Regional Identity: Some Examples on Private Radio}

Regional language and culture programming on private radio will target a specific audience defined by ethnicity where the audience defines itself ethnically, as in the case, for example, with transmigrant and displaced communities. Javanese communities outside of Java are well represented on private radio. Medan has two Javanese-audience radio stations, the FM Radio Merpati, which broadcasts Javanese music, and the AM Radio Pasopati which broadcasts ludruk, ketoprak, wayang orang, wayang kulit, gamelan request programs, keroncong, macapatan, and readings of Javanese novels and short stories. Some of these programs, like ludruk, are now more difficult to find on radio in central Java itself. ${ }^{50}$ Lampung's transmigrant Javanese community is serviced by Radio Pramudya Sukadana, which devotes a full 50 percent of broadcast time to Javanese gamelan, ketoprak and dagelan (humor) and sponsors local performances. ${ }^{51}$ Jakarta has three radio stations that target Javanese audiences and give priority to Javanese culture-Radio Safari, Radio Kayu Manis, and P2SC-and Bandung has one, Radio Mutiara. In Palu, Central Sulawesi, Radio Rinda Mutiara programs Javanese, Bugis and Makassar music for its varied migrant communities. Jakarta also has radio stations broadcasting to migrant Minang communities. In Surabaya, a small dangdut station, Radio Cakrawala Bhakti, broadcasts community announcements in Madurese to the migrant Madurese there. PRSSNI radio survey figures for all these stations show that, apart from the Javanese radio stations in Jakarta, Bandung and Medan which target a mid-income audience, all other stations target the low-income bracket. Interestingly, most of these stations claim a higher percentage of women listeners (an average of around 55-60 percent). The most varying factor is age group, although the urban Javanese stations in Medan, Jakarta and Bandung all claim the thirty to thirty-nine-year-old age group to be their largest audience.

In more heterogeneous cultural situations, too, radio stations can target specific ethnic backgrounds to reach a clear audience segment. North Sumatra is a striking example: apart from its two Javanese radio stations, North Sumatra also has Batak stations (Radio Kordopa in Medan and Radio Swara Jupti Indah in Sibolga), a Karo station (Radio Budaya Karo in Simalungun, a Simalungun station (Radio Niaga dan Budaya Simalungun), a Deli Malay station (Radio Alnora in Medan), and a Minang station (Radio Kamasutra). Where a resident community becomes increasingly marginalized, again cultural-ethnic identification becomes an audience identification

\footnotetext{
50 For further on Radio Pasopati see "Pasopati si Radio Pujakesuma," Kompas (February 10, 1994): 1, and "'Radio Pasopati' Medan, Membuat Acara Pengobat Rindu Kampung Halaman," Kompas, June 26, 1996, p. 21.

${ }^{51}$ For further on Radio Pramudya Lampung Tengah see "Gema Budaya Jawa Di Lampung," Eksponen II (March 1994): 9 and "Usung Siaran Gending Jawa," Eksponen II (June 1995): 13.
} 
factor, as for example in Jakarta, where the radio station established by the late Benyamin S. seven years ago-called Ben's Radio-targets a Betawi audience, and with its programming of 70 percent dangdut, supplemented by Gambang Kromong, Lenong, Jakarta history, and varying degrees of Betawi dialect, has quickly risen to become the ninth-rated radio station in the larger Jakarta area. ${ }^{52}$ More predictably, the target audience for Ben's Radio falls in the low-income bracket (but is rising). The North Sumatran stations, however, claim to cover "all segments," which indicates that in heterogeneous locales, ethnic-cultural specificity is indeed the clearer determinant of audience than income.

Where there is wide ethnic homogeneity and regional identity does not in itself target a local audience, then other factors come into play. As mentioned above, in Central Java, for example, where broadcasting Javanese cultural programs does not in itself target a specific audience, distinctions between different age groups and economic classes are made through a choice of how to address that identity, for example through the degree of explicit Javaneseness and the style of cultural programming. Two examples from Yogyakarta indicate how private radio stations express this difference and alter their cultural profile and programming to cater to specific audiences. We consider here Radio Retjo Buntung in the city of Yogyakarta itself, and Radio MBS in Kotagede. ${ }^{53}$

There are fifteen private radio stations in the larger Yogyakarta area (spread over five kabupaten), and nine in the city, of which four are FM and five are AM. Radio Retjo Buntung is one of the oldest stations, established in 1967. Approximately 20 percent of Retjo Buntung's programming is devoted to Javanese culture, but when the station changed from AM to FM in 1991, its audience and programming changed. As an AM station, Retjo Buntung had targeted the mid- to lower income groups and particularly the thirty-plus age group, but since switching to FM, it has targeted a mid- to upper income audience with a wider age-group spread. Over the past few years, Retjo Buntung has decreased its number of ketoprak broadcasts, but has doubled its broadcasts of wayang kulit. It has also added broadcasts of macapat and culturaldiscussion/appreciation. Programming of gamelan music has remained constant. Radio Retjo Buntung's cultural programming now includes Javanese radio dramas (sandiwara), discussions on cultural themes (apresiasi Wayang, Sarasehan Kebudayaan) ketoprak, a "chat" program (Obrolan Pak Guno), gamelan music, readings of Javanese novels and short stories, and wayang kulit, including a station-sponsored live wayang kulit performance once a month. Of all these, only the readings of Javanese novels and short stories still specifically targets the thirty-plus age-group, but this is also the most popular of Retjo Buntung's specifically Javanese programs.

Radio MBS (Mataram Buana Suara) in Kotagede is a relatively new AM station, established in 1988, which advertises itself as a dangdut station with the motto "the

\footnotetext{
52 See The Jakarta Post, June 30, 1996, p. 3. According to the station staff, it has actually risen to the eighth rating.

53 I am very grateful to Mr. Martan Kiswoto of Radio MBS and Mr. Anton Sutopo of Radio Retjo Buntung who explained the policy of their stations to me, and to Sapto Raharjo of Radio Geronimo, who accompanied me during these interviews. More information on Retjo Buntung can be found in "Retjo Buntung, Bersiaran Untuk Keluarga," Cakram (January 1994): 48-49
} 
station that develops culture and the arts." 54 Its audience is in the lower to mid-income bracket, all ages, and the station's geographical situation on the outskirts of Yogyakarta defines its audience as semi-urban. Over the past five years, MBS has targeted a more specialized low economy local audience, and has increased its percentage of dangdut (now 87 percent of programming), and ceased programming ketoprak, Javanese radio dramas (sandiwara) and gamelan programs (klenengan). Programming of wayang kulit and keroncong has been maintained, and the station works closely with the community to sustain these activities as community events. Since 1993, MBS has sponsored a live wayang kulit performance every thirty-five days, working together with the Yogyakarta wayang association Ganasedi (Lembaga Pembina Seni Pedalangan), and paying special attention to training for young dalangs and giving them opportunities to perform. Keroncong is featured three times a week, with a live performance broadcast once a month programmed by an associated club made up of around fifty groups, the Paguyuban Orkes Keroncong Pembantu Siaran Radio MBS. The station also runs a onceweekly macapat and Javanese humor (guyon) program.

In both these examples, programming of Javanese cultural arts is an integral part of the radio station's image, but the choice of programming varies in order to target different, select audiences which are distinguished from one another primarily by economic class. The FM station's more mid- to upper class image calls for a heavier dose of Javanese language in its programming, with dramas, novel readings, and ketoprak, and also programs of gamelan music. MBS's low-income audience is presented with a much lower percentage overall of Javanese programming, and no gamelan or Javanese language drama (ketoprak or sandiwara) with the clear exception of wayang kulit, which remains popular on Radio MBS as on all Yogyakarta radio stations.

The unusual case of Radio Shinta Buana in Bandung gives us a last example showing how a private radio station may shape its programming of regional culture and language to target a specific audience. When changing from AM to FM in 1995, Radio Shinta Buana increased its percentage of Sundanese programming, developed its own production of contemporary Sundanese programs, and now lists its top five programs as Sundanese. ${ }^{55}$ Radio Shinta Buana is one of thirty-three private stations in Bandung, of which eighteen are FM stations (West Java in general has the highest number of private radio stations), and its popularity now ranks in the top five. This station has been extremely successful in defining its audience segment and tailoring its program specifically to this audience's contemporary sense of its regional identity.

Radio Shinta Buana is extremely clear about its audience. The station director described its middle-income audience as "close to oral tradition and story-telling, very much attached to popular figures, easily influenced, humor-loving, and with a strong regional pride but loose sense of 'tradition.' It is an audience that feels regional pride in a sense of community rather than anything associated with the term 'tradition' (which it associates increasingly with religion), and this community sense is expressed

\footnotetext{
54 See further "Radio MBS Yogya Melestarikan Budaya Adiluhung," Eksponen III (November 1993): 7.

$55 \mathrm{I}$ am very grateful to the station director, $\mathrm{Mr}$ Yousrul Raffle, and his staff for giving me such an excellent presentation about Radio Shinta Buana. More about this station and its programming can be found in Eksponen III (December 1993): 7; Eksponen IV (August 1995): 11; and Eksponen IV (November 1995): 14.
} 


\section{Jennnifer Lindsay}

particularly through language (inserting Sundanese into everyday Indonesian)-but even through small signs like sharing Bandung 'D' car-registration plates."

Shinta Buana has successfully targeted a middle-income, young, Sundanesespeaking audience by creating its own programs rather than broadcasting already available material. The production team retains copyright over all the new material created, allowing resale to stations outside of Bandung. Taking the dongeng/ storytelling tradition as its point of departure, Radio Shinta Buana has developed this into a contemporary form of oral entertainment on radio, presenting dongeng in a lighthearted, tongue-in-cheek way, with a featured young presenter (Wak Kepoh) who has quickly become a popular community figure. The station broadcasts five Sundanese programs a day, three readings of dongeng (Sangkuriang, Tangkuban Perahu, Si Rawing), one program of sisindiran (pantun). The station's current top-ranking program, Dongpless (from Dongeng Plesetan), scheduled during a prime generallistening time between three and four in the afternoon, tells of the fantastic Siluman creatures who came to earth and now roam through time to study the supposedly more advanced ways of human beings. Dongpless is presented by one storyteller (juru catur) assisted by four commentators (alok). The program script is written by Ahmad Afandi. Presented with electronic music replacing the kecapi (the kecapi is still used in the other dongeng programs), but still alternating poetry (tembang) and prose, and with inserts of "Sundanese rap," the tone of Dongpless is humorous and ironic-one episode tells, for example, of when the Siluman were sent to earth to learn about parliament from human beings, and on visiting the DPR, the creatures learned that what one should do is sleep and collect one's pay.

\section{Conclusion}

The enduring tradition of radio in Indonesia is as local community expression. This was the role that radio adopted when first introduced to the Netherlands East Indies, and it continues to thrive in the world of private radio today. In the 1930s, the "Eastern" stations in particular drove home their sense of locality through broadcasts of local music, transmitted predominantly as live performance. The content of local culture was something familiar, but the fascination was in the technology of broadcasting it. Today, radio broadcast technology is entirely familiar, but in a context of national culture, state-determined diets of national information, and national and international television broadcasting, the community-oriented voice of private radio is a fascinating haven for local identities in Indonesia.

The picture emerges of a vibrant, decentralized world in which local identities thrive and find varied expressions. Radio audiences in Indonesia are finding their own way of accepting new media like television. Certainly television is not merely replacing radio, and private radio in particular appears to be securing for itself a strong niche with ever more segmented programming within its local community focus. Local communities' perceptions of and relationships to regional cultural identity, as demonstrated in local private radio, are extremely varied, complex, and changeable. What is clear, however, is that regional identity and culture remain deeply ambiguous to Indonesians-on the one hand, often backward, lower-class, kampungan and "traditional," and on the other hand, intimate, necessary, part of daily life, and at times, a status symbol. Regional cultural identity is an integral part of life, particularly 
an uneasiness about it which Shinta Buana captures so effectively in its light-hearted approach to "cultural tradition."

The future of cultural programming on private radio is tied to the broadcasting role of private radio itself. If private radio becomes more national, through the development of networks and change in legislation that would allow wider broadcasting through use of satellite, then perhaps the local community focus, including the regional cultural identification of private radio, would be lost. But on the other hand, a local focus - which has been so much part of the broadcasting genre -may merely develop and spread in other broadcast media, finding new niches. Recent developments indicate a trend in this direction, as some television stations have increased regional cultural programming. The recent programming of Javanese wayang kulit and Sundanese wayang golek on Indosiar are interesting developments, although so far such programming is limited to majority regional cultures, and it has yet to be seen whether such television broadcasts compete with radio broadcast, merely complement, or even stimulate them.

Private radio in Indonesia is a rich resource for study of social change and the changing images of regional identity. This paper has focused on only a few examples of one aspect of programming, yet the resource is there for study of language use, radio as oral tradition, changing popularity of musical styles, and economic change in the community. Much scholarly attention has been given to the print media and now to television, but radio seems to have been largely ignored. And yet, like regional cultural identity, it is there, all around, in Indonesia. 
